\title{
Correlation of six methods for typing nosocomial isolates of Acinetobacter baumannii
}

\author{
M. A. MARCOS, M. T. JIMENEZ DE ANTA and J. VILA* \\ Department of Microbiology, Faculty of Medicine, Hospital Clinic, University of Barcelona, Villarroel 170, \\ Barcelona 08036, Spain
}

\begin{abstract}
Summary. A comparative study of biotyping, antimicrobial susceptibility, whole-cell protein analysis, plasmid analysis, pulsed-field gel electrophoresis of chromosomal DNA and polymerase chain reaction with arbitrary primers of Acinetobacter baumannii isolates from three large hospitals was performed to determine the best markers for epidemiological purposes. Ninety-two isolates were included : 38 belonged to a previously described outbreak and 54 were randomly selected from sporadic cases of infection. Biotyping, whole-cell protein and plasmid analysis were the least discriminatory methods, whereas antimicrobial susceptibility and polymerase chain reaction with arbitrary primers showed moderate discriminatory power. Typing based on pulsed-field gel electrophoresis of chromosomal DNA appeared to be the best discriminatory method (discrimination index of 0.9623). The addition of polymerase chain reaction with arbitrary primers or antimicrobial susceptibility to pulsed-field gel electrophoresis of chromosomal DNA did not further increase the discriminatory power.
\end{abstract}

\section{Introduction}

In recent years, outbreaks of infection caused by Acinetobacter spp. have become a growing concern in hospitals. ${ }^{1-3}$ Acinetobacter spp. are widely distributed in the hospital environment and have been isolated from various inanimate sources such as ventilatory equipment, blood collection tubes, mattresses and plastic urinals. However, it seems that the skin of patients and staff is the most likely source for the majority of outbreaks of nosocomial acinetobacter infection..$^{4-5}$

Acinetobacter baumannii is the species most often associated with nosocomial infection. ${ }^{6}$ This organism is capable of causing life-threatening infections including bacteraemia, pneumonia and meningitis. ${ }^{7-9}$ The increasing importance of infections caused by Acinetobacter spp., and the multi-resistance of the strains involved, ${ }^{10-11}$ render studies of epidemiology and antibiotic resistance necessary for the prevention of further infections with this organism. There is no generally accepted typing scheme for epidemiological studies of Acinetobacter isolates, although various methods have been used. They include phage typing, ${ }^{12}$ biotyping, ${ }^{6}$ determination of antibiotic susceptibility

Received 17 May 1994; revised version accepted 20 Oct. 1994 * Correspondence should be sent to Professor J. Vila. patterns, ${ }^{11-13}$ whole-cell ${ }^{14-15}$ and cell envelope ${ }^{16}$ protein electrophoresis, plasmid analysis, ${ }^{3,17,18}$ ribotyping, ${ }^{19,20}$ polymerase chain reaction fingerprinting ${ }^{21}$ and DNA restriction fragment length polymorphism determined by pulsed-field gel electrophoresis (PFGE). ${ }^{22,23}$

The purpose of this study was to describe and compare the results obtained with several of these methods - biotyping, antimicrobial susceptibility, whole-cell protein, plasmid analysis, PFGE of chromosomal DNA and polymerase chain reaction with arbitrary primers (AP-PCR) - to analyse 92 isolates of $A$. baumannii from three hospitals in Barcelona, obtained during a 3-year period.

\section{Materials and methods}

\section{Bacterial strains}

A total of 92 isolates of $A$. baumannii from different clinical specimens obtained from patients admitted to three Barcelona hospitals was examined; 48 isolates came from Hospital Clínico, 19 from Hospital de la Santa Cruz y San Pablo and 25 from Hospital Valle de Hebrón. Thirty-eight of the isolates belonged to a previously defined outbreak in the Hospital Clínico during the period Sept. $1988-$ Aug. $1989 ;{ }^{3}$ the re- 
maining 54 isolates were randomly selected from sporadic cases of $A$. baumannii infections from the three above-mentioned hospitals.

\section{Biotyping}

Isolates were identified as $A$. baumannii by standard biochemical procedures and the API 20NE system (bioMérieux). The biotype was determined by means of the utilisation of six carbon sources (levulinate, citraconate, L-phenylalanine, L-phenylacetate, 4hydroxybenzoate, L-tartrate), as described previously. ${ }^{6}$

Strains of each biotype (kindly provided by Dr P. Bouvet Unité des Entérobactéries, Institut Pasteur, Paris, France) were used as controls.

\section{Antimicrobial susceptibility}

Susceptibility to antimicrobial agents was determined by the Bauer disk diffusion method. ${ }^{24}$ Disks were obtained from BBL (Becton Dickinson Microbiology Systems Cockeysville, MD, USA); ampicillin $10 \mu \mathrm{g}$; mezlocillin $75 \mu \mathrm{g}$; piperacillin $100 \mu \mathrm{g}$; cefotaxime $30 \mu \mathrm{g}$; cefoxitin $30 \mu \mathrm{g}$; ceftriaxone $30 \mu \mathrm{g}$; cefuroxime $30 \mu \mathrm{g}$; cefalothin $30 \mu \mathrm{g}$; chloramphenicol $30 \mu \mathrm{g}$; gentamicin $10 \mu \mathrm{g}$; netilmicin $30 \mu \mathrm{g}$; tobramycin $10 \mu \mathrm{g}$; amikacin $30 \mu \mathrm{g}$; ciprofloxacin $5 \mu \mathrm{g}$ and imipenem $10 \mu \mathrm{g}$.

\section{Whole-cell protein electrophoresis}

Strains were grown overnight at $37^{\circ} \mathrm{C}$ in brain-heart infusion broth. Cells were collected by centrifugation and washed twice in phosphate-buffered saline. The pellets were resuspended in equal volumes of sample treatment buffer $(0.0625 \mathrm{~m}$ Tris- $\mathrm{HCl}, \mathrm{pH} 6.8, \mathrm{SDS} 2 \%$, glycerol $10 \%$, 2-mercaptoethanol $5 \%$ ), heated at $100^{\circ} \mathrm{C}$ in a water-bath for $10 \mathrm{~min}$. SDS-PAGE was performed by the method described by Laemmli, ${ }^{25}$ with an acrylamide gradient of $10-20 \%$ in the running gel. Boiled samples $(20 \mu \mathrm{l})$ were applied to the gel and electrophoresed in a Protean gel apparatus (BioRad) at a voltage of $60 \mathrm{~V}$ to run the sample through the stacking gel, after which the voltage was increased to $200 \mathrm{~V}$. Gels were stained with Coomassie Brilliant Blue. The mol. wt standards were phosphorylase B $(97.4 \mathrm{kDa})$, bovine albumin $(66.2 \mathrm{kDa})$, ovalbumin $(45 \mathrm{kDa})$, carbonic anhydrase $(31 \mathrm{kDa})$, trypsin inhibitor $(21.5 \mathrm{kDa})$ and lysozyme (14.4 kDa) (BioRad, Richmond, CA, USA). The resulting patterns were scanned with a Bio Image Electrophoresis Analyzer (Millipore), by means of the unweighted pair group method using averages algorithm (UPGMA). ${ }^{14}$

\section{Plasmid analysis}

Plasmid DNA was isolated essentially as described in Birnboim and Doly's alkaline precipitation method. ${ }^{26}$ The sample was analysed by horizontal electrophoresis in agarose $0.7 \%$, and plasmid DNA bands were visualised under UV illumination after being stained with ethidium bromide.

\section{PCR with arbitrary primers}

Bacteria were grown on MacConkey agar overnight. Half a colony of each isolate was suspended in $25 \mu \mathrm{l}$ of distilled sterile water, and boiled for $10 \mathrm{~min}$. After a short centrifugation, $25 \mu \mathrm{l}$ of a reaction mixture containing $20 \mathrm{~mm}$ Tris- $\mathrm{HCl} \quad(\mathrm{pH} \quad 8.8), 100 \mathrm{mM}$ potassium chloride, $3.0 \mathrm{~mm}$ magnesium chloride, gelatin $0 \cdot 1 \%, 400 \mu \mathrm{M}$ deoxynucleoside triphosphates and $0.25 \mu \mathrm{M}$ or $1 \mu \mathrm{M}$ primer was added, together with $2.5 \mathrm{U}$ of Taq polymerase from Thermus aquaticus (Boehringer Mannheim, Germany). The reaction was overlaid with oil and subjected to two cycles through the following temperature profile: $94^{\circ} \mathrm{C}$ for $5 \mathrm{~min}$ to denature, $40^{\circ} \mathrm{C}$ for $5 \mathrm{~min}$ for low stringency annealing of primer and $72^{\circ} \mathrm{C}$ for $5 \mathrm{~min}$ for extension. This temperature profile was followed by 40 high stringency cycles: $94^{\circ} \mathrm{C}$ for $1 \mathrm{~min}, 60^{\circ} \mathrm{C}$ for $1 \mathrm{~min}$ and $72^{\circ} \mathrm{C}$ for 1 min. PCR assay was performed in a DNA Thermal Cycler 480 (Perkin-Elmer Cetus, Emeryville, CA, USA). The sequence of primer used was 5'GTT GTA AAA CGA CGG CCA GT3' (M13 forward primer). Primer was obtained from MedProbe, Oslo, Norway. Amplification products were analysed by electrophoresis in agarose $2 \%$ gel and detected by staining with ethidium bromide.

\section{Chromosomal analysis by PFGE}

Genomic DNA was prepared in agarose plugs as described previously. ${ }^{22}$ It was then incubated with a mixture of $0.5 \mathrm{~m}$ EDTA, SDS $1 \% \mathrm{w} / \mathrm{v}$, sarcosyl $1 \%$ $\mathrm{w} / \mathrm{v}$ and $1 \mathrm{mg}$ of pronase $\mathrm{E}$ (Serva) $/ \mathrm{ml}$ for $48 \mathrm{~h}$ at $37^{\circ} \mathrm{C}$, with a change of solution after $24 \mathrm{~h}$. Protein digestion products were removed by washing the inserts twice for $1 \mathrm{~h}$ at $50^{\circ} \mathrm{C}$ in $10 \mathrm{~mm}$ Tris $-0.1 \mathrm{~mm}$ EDTA (pH 7.5)-1 mm phenylmethylsulphonyl fluoride and three times in Tris-EDTA alone for $1 \mathrm{~h}$ each at room temperature. One insert of DNA was incubated overnight with $50 \mathrm{U}$ of $A p a \mathrm{I}$ or $50 \mathrm{U}$ of $S m a \mathrm{I}$ (Promega) following the manufacturer's recommendations. The DNA fragments generated were separated in a pulsed-field agarose $1 \%$ gel (BioRad) that was prepared and run in Tris-borate-EDTA (TBE) buffer on a contour-clamped homogeneous field apparatus (CHEF-DR2; BioRad). The conditions for electrophoresis were $200 \mathrm{~V}$ for $24 \mathrm{~h}$, with pulse time ranging from 5 to $8 \mathrm{~s}$. Thereafter, the gels were stained with ethidium bromide and photographed.

\section{Discriminatory index}

The index of discriminatory power was calculated following Hunter and Gaston's equation. ${ }^{27}$ 


\section{Reproducibility}

This was the ability of a technique to yield the same result when the same strain was tested three times and was classified as moderate, good and excellent.

\section{Results}

\section{Biotyping}

The API-20NE system identified all isolates as $A$. baumannii, with three different analytical profile index numbers: 0041073, 0041051; 0041473. Changes occurred in the gluconate, adipate and phenylacetate reactions. Seven biotypes were observed among the 92 A. baumannii studied by a six carbon-source system. Biotypes 2, 9 and 12 represented $89 \cdot 1 \%$ of $A$. baumannii strains (table I).

\section{Antimicrobial susceptibilities}

Table II shows the antibiotic susceptibilities of the strains isolated. Almost all the isolates were resistant to ampicillin, and $>50 \%$ were also resistant to piperacillin, cefotaxime, and ceftazidime. Susceptibility to gentamicin, tobramycin, amikacin and netil-
Table II. Antimicrobial susceptibility patterns of $A$ baumannii isolates

\begin{tabular}{lllllllll}
\hline Antibiotic & I & II & III & IV & V & VI & VII & VIII \\
\hline Ampicillin & R & R & R & R & R & R & R & R \\
Cefotaxime & S & R & MS & R & MS & MS* & MS & R \\
Cefoxitin & R & R & R & R & R & R & R & R \\
Ceftriaxone & S & MS & S & MS & MS & MS* & R & R \\
Cefuroxime & MS & R & R & R & R & MS & R & R \\
Cefalothin & R & R & R & R & R & R & R & R \\
Mezlocillin & S & R & R & MS & MS & MS* & R & R \\
Piperacillin & S & R & R & MS & MS & MS* & R & R \\
Chloramphenicol & R & R & R & R & R & R & R & R \\
Gentamicin & S & R & R & R & R & S & R & R \\
Netilmicin & R & S & R & S & R & S & S & R \\
Tobramycin & S & R & I & R & R & S & R & R \\
Amikacin & S & R & S & S & S & S & R & R \\
Ciprofloxacin & S & S & R & S & S & S & R & R \\
Imipenem & S & S & S & S & S & S & S & S \\
\hline
\end{tabular}

$R$, resistant, I, intermediate, S, susceptible, MS, moderately susceptible.

* Variable susceptibility to these antibiotics.

micin enabled the definition of seven phenotypic resistance patterns; among those, GENs, TOBs, AMKs, NETr (group I), GENr, TOBr, AMKr, NETs (group II), GENs, TOBs, AMKs, NETs (group VI), were the most frequently encountered. All strains were

Table I. Classification of $A$. baumannii isolates by different epidemiological markers

\begin{tabular}{|c|c|c|c|c|c|c|c|c|}
\hline \multirow[b]{2}{*}{ Hospital } & \multirow{2}{*}{$\begin{array}{c}\text { Laboratory no.* } \\
\text { (number of isolates) }\end{array}$} & \multicolumn{2}{|c|}{ Biotyping } & \multirow[b]{2}{*}{ Antibiogram } & \multirow{2}{*}{$\begin{array}{c}\text { Plasmid } \\
\text { profile }\end{array}$} & \multirow{2}{*}{$\begin{array}{l}\text { Protein } \\
\text { patterns }\end{array}$} & \multirow{2}{*}{$\begin{array}{l}\text { PFGE } \\
\text { type }\end{array}$} & \multirow{2}{*}{$\begin{array}{l}\text { AP-PCR } \\
\text { profile }\end{array}$} \\
\hline & & $\begin{array}{c}\text { API-profile } \\
\text { NE }\end{array}$ & Biotype & & & & & \\
\hline $\begin{array}{l}\text { H. Clinico y } \\
\text { Provincial }\end{array}$ & $\begin{array}{l}41(21) \dagger \\
36(17) \dagger \\
661(5) \\
724(5)\end{array}$ & $\begin{array}{l}0041051 \\
0041073 \\
0041051 \\
0041073\end{array}$ & $\begin{array}{r}12 \\
9 \\
12 \\
9\end{array}$ & $\begin{array}{l}\text { II } \\
\text { II } \\
\text { VII } \\
\text { VIII }\end{array}$ & $\begin{array}{l}\mathrm{a} \\
\mathrm{f} \\
\mathrm{b} \\
\mathrm{e}\end{array}$ & $\begin{array}{l}\text { B1 } \\
\text { B1 } \\
\text { B1 } \\
\text { A1 }\end{array}$ & $\begin{array}{l}7 \mathrm{c} \\
3 \\
7 \mathrm{~b} \\
6\end{array}$ & $\begin{array}{r}7 \\
14 \\
7 \\
2\end{array}$ \\
\hline $\begin{array}{l}\text { H. Valle de } \\
\text { Hebron }\end{array}$ & $\begin{array}{l}74(1) \\
86(2) \\
83(1) \\
58(2) \\
61(1) \\
92(1) \\
60(1) \\
68(1) \\
65(1) \\
72(1) \\
88(3) \\
93(2) \\
67(1) \\
70(1) \\
77(3) \\
78(1) \\
81(1) \\
91(1)\end{array}$ & $\begin{array}{l}0041473 \\
0041473 \\
0041473 \\
0041473 \\
0041473 \\
0041473 \\
0041473 \\
0041473 \\
0041473 \\
0041473 \\
0041051 \\
0041051 \\
0041051 \\
0041051 \\
0041073 \\
0041073 \\
0041073 \\
0041073\end{array}$ & $\begin{array}{r}9 \\
9 \\
6 \\
6 \\
12 \\
11 \\
8 \\
9 \\
2 \\
6 \\
12 \\
12 \\
12 \\
12 \\
9 \\
9 \\
9 \\
9\end{array}$ & $\begin{array}{l}\text { VI } \\
\text { VI } \\
\text { VI } \\
\text { VI } \\
\text { VI } \\
\text { VI } \\
\text { VI } \\
\text { VI } \\
\text { VI } \\
\text { VI } \\
\text { II } \\
\text { II } \\
\text { II } \\
\text { II } \\
\text { V } \\
\text { V } \\
\text { V } \\
\text { V }\end{array}$ & $\begin{array}{l}\mathrm{g} \\
-t \\
- \\
- \\
- \\
\mathrm{d} \\
- \\
- \\
\mathrm{a} \\
\mathrm{a} \\
\mathrm{a} \\
- \\
- \\
-\end{array}$ & $\begin{array}{l}\text { B1 } \\
\text { F } \\
\text { B2 } \\
D \\
\text { B1 } \\
\text { B2 } \\
\text { E } \\
\text { C } \\
\text { B1 } \\
\text { D } \\
\text { B1 } \\
\text { B1 } \\
\text { B1 } \\
\text { B1 } \\
\text { A1 } \\
\text { A1 } \\
\text { A1 } \\
\text { A1 }\end{array}$ & $\begin{array}{r}14 \\
9 \\
15 \\
8 \\
4 \\
20 \\
12 \\
13 \\
10 \\
11 \\
7 \mathrm{~d} \\
7 \mathrm{c} \\
7 \mathrm{e} \\
7 \mathrm{a} \\
1 \mathrm{a} \\
2 \\
1 \mathrm{~b} \\
1 \mathrm{c}\end{array}$ & $\begin{array}{r}5 \\
15 \\
8 \\
6 \\
4 \\
13 \\
3 \\
12 \\
8 \\
1 \\
7 \\
7 \\
7 \\
7 \\
2 \\
2 \\
2 \\
2\end{array}$ \\
\hline $\begin{array}{l}\text { H. Sta Cruz } \\
\text { y S. Pablo }\end{array}$ & $\begin{array}{r}31(5) \\
175(2) \\
188(6) \\
182(1) \\
183(1) \\
198(2) \\
167(1) \\
37(1)\end{array}$ & $\begin{array}{l}0041473 \\
0041473 \\
0041073 \\
0041073 \\
0041473 \\
0041473 \\
0041473 \\
0041473\end{array}$ & $\begin{array}{l}2 \\
2 \\
9 \\
9 \\
6 \\
5 \\
9 \\
8\end{array}$ & $\begin{array}{l}\text { III } \\
\text { III } \\
\text { IV } \\
\text { IV } \\
\text { VI } \\
\text { VI } \\
\text { VI } \\
\text { VI }\end{array}$ & $\begin{array}{l}- \\
\bar{c} \\
\mathrm{c} \\
- \\
- \\
-\end{array}$ & $\begin{array}{l}\text { A2 } \\
\text { A2 } \\
\text { B1 } \\
\text { B1 } \\
\text { A1 } \\
\text { B1 } \\
\text { E } \\
\text { D }\end{array}$ & $\begin{array}{c}16 \mathrm{a} \\
16 \mathrm{~b} \\
5 \mathrm{a} \\
5 \mathrm{~b} \\
19 \\
21 \\
17 \\
18\end{array}$ & $\begin{array}{r}8 \\
8 \\
11 \\
11 \\
16 \\
5 \\
10 \\
9\end{array}$ \\
\hline
\end{tabular}

PFGE, pulsed field gel electrophoresis; AP-PCR, polymerase chain reaction with arbitrary primers.

*Strain type.

$\dagger$ Isolates from outbreak.

† Strains without detectable plasmid DNA. 


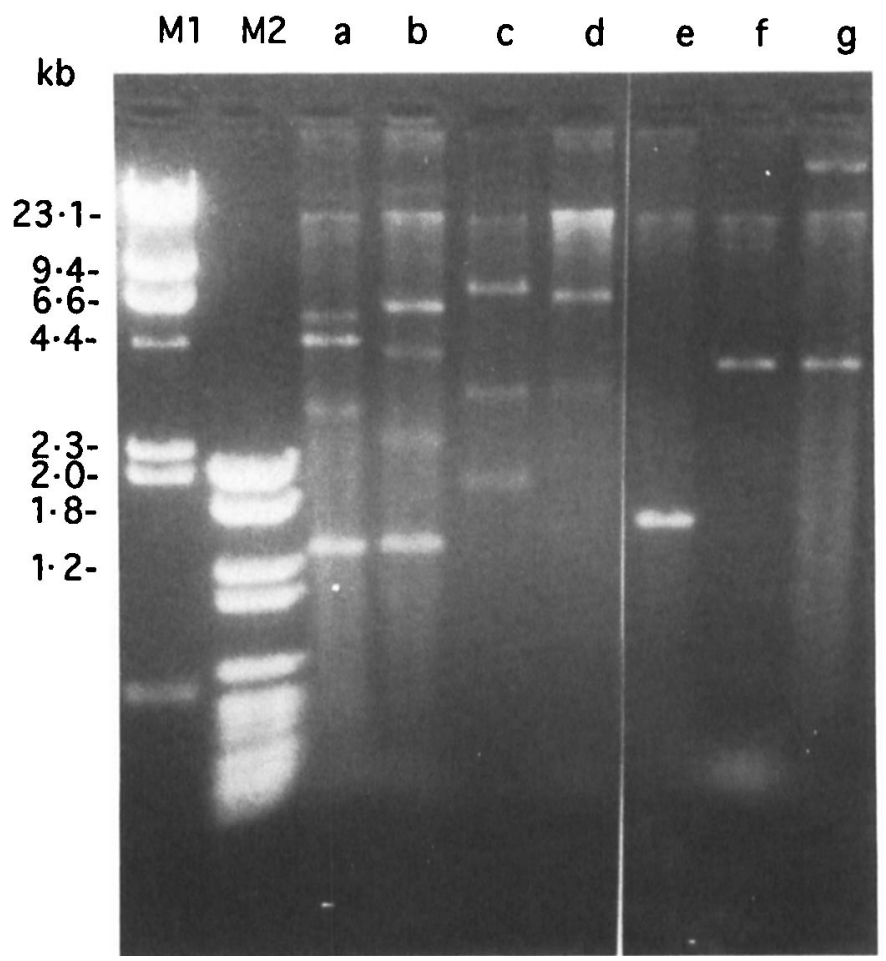

Fig. 1. Plasmid DNA patterns. Lane M1, HindIII-digested $\lambda$; M2, DNA mol. wt marker VI (pBR328 DNA-BgII + pBR328 DNA-HinfI). Lane a, strains $41,88,93,67$ and $70 ; \mathbf{b}$, strain $661 ; \mathbf{c}$, strains 188 and $182 ; \mathbf{d}$, strain $60 ; \mathbf{e}$, strain $724 ; \mathbf{f}$, strain 36; g, strain 74 .

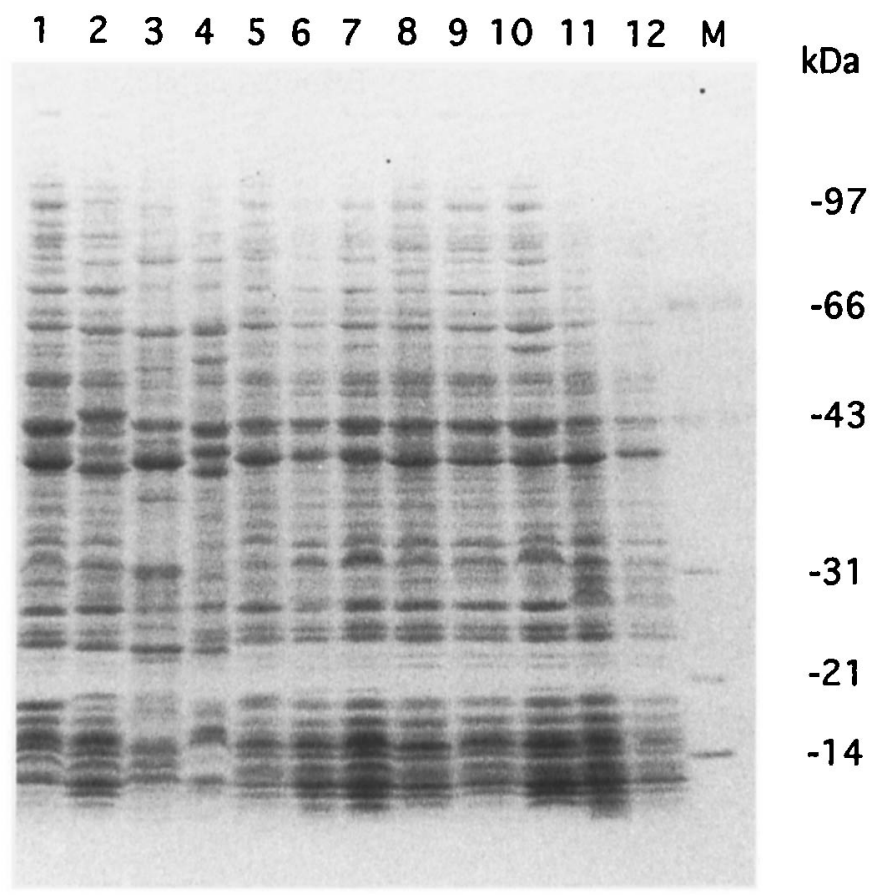

Fig. 2. Whole-cell protein SDS-PAGE patterns. Molecular size standards are shown on the right. Lane 1, strain from group F; 2, strain from group E; 3, strain from group D; 4, strain from group C; 5 , strain from group B2;6 and 7, strains from group A1;8-11, strains from group $\mathrm{B} 1 ; \mathbf{1 2}$, strain from group A2.

susceptible to imipenem but $18 \%$ were resistant to ciprofloxacin.

\section{Plasmid profiles}

Plasmid profile analysis revealed seven profiles (table I) (fig. 1): a, b, c, d, e, f, g, "a" was the predominant pattern $(30.4 \%)$. No plasmids were detected in $30.4 \%$ of the strains, $24 \%$ of strains harboured only one plasmid and $45.6 \%$ contained two or more plasmids.

\section{$S D S-P A G E$ protein patterns}

One-dimensional SDS-PAGE of whole-cell protein extracts produced patterns containing $30-40$ discrete 

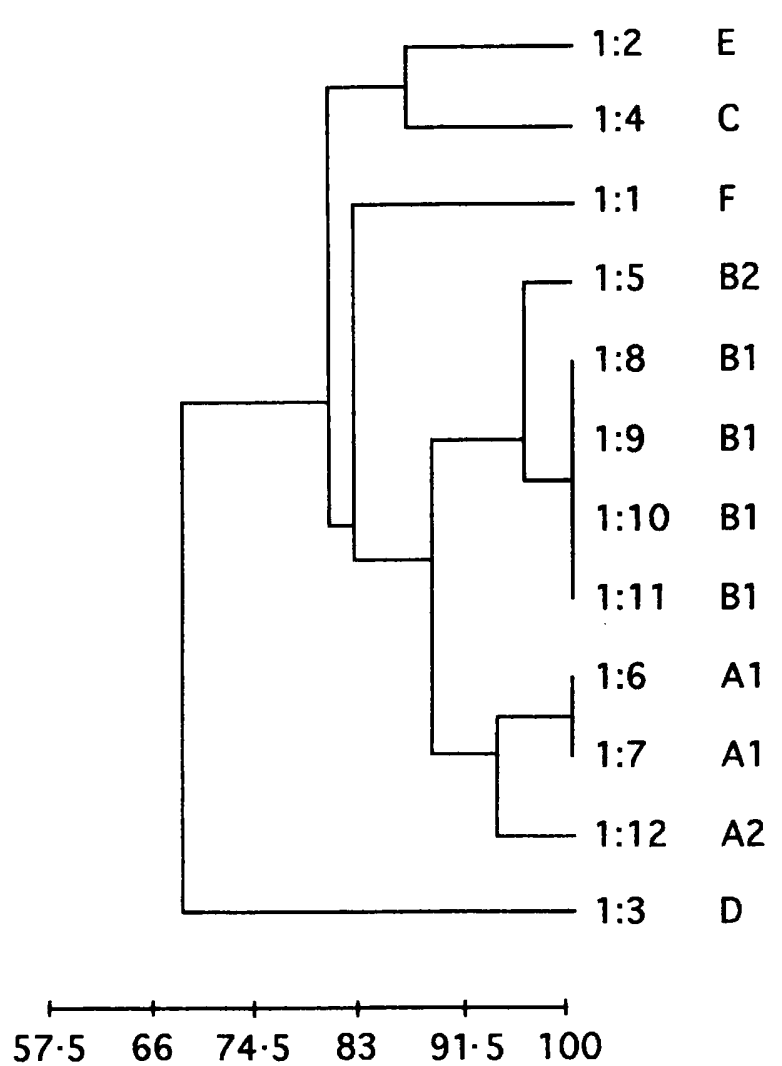

\section{Percentage similarity}

Fig. 3. Dendrogram showing percentage similarity of eight electrophoretic protein patterns, analysed by the unweighted pair group method using averages (UPGMA) algorithm. bands with molecular sizes varying from 15 to $100 \mathrm{kDa}$. The region between $21 \mathrm{kDa}$ and $66 \mathrm{kDa}$ proved to be the most discriminatory (fig. 2).

For the purpose of this study the patterns were arbitrarily coded with capital letters; isolates with a similarity $>90 \%$ were given the same capital letter followed by a number (table I). Six patterns (A, B, C, $D, E$ and $F$ ) were observed with similarity between them ranging from 68 to $88 \%$ (fig. 3 ).

\section{PCR fingerprinting}

The 92 bacterial strains were subjected to PCR with M13 forward primer. Two different primer concentrations were assayed $(0.25 \mu \mathrm{M}$ and $1 \mu \mathrm{M})$. A decrease in the concentration of primers resulted in an overall synthesis of longer amplicons, and smaller fragments tended to disappear from the DNA banding patterns. However, the primer concentration did not modify the distribution of groups.

PCR analysis revealed 16 different banding patterns (table I). PCR patterns generated between two and seven DNA fragments of $0 \cdot 3-2 \cdot 2 \mathrm{~kb}$. The small differences in fingerprinting patterns manifested by minor DNA fragments were demonstrated repeatedly. However, a decrease in the intensity of the longer bands was occasionally observed (fig. 4).

\section{Chromosomal analysis by PFGE}

Twenty completely different restriction fragment

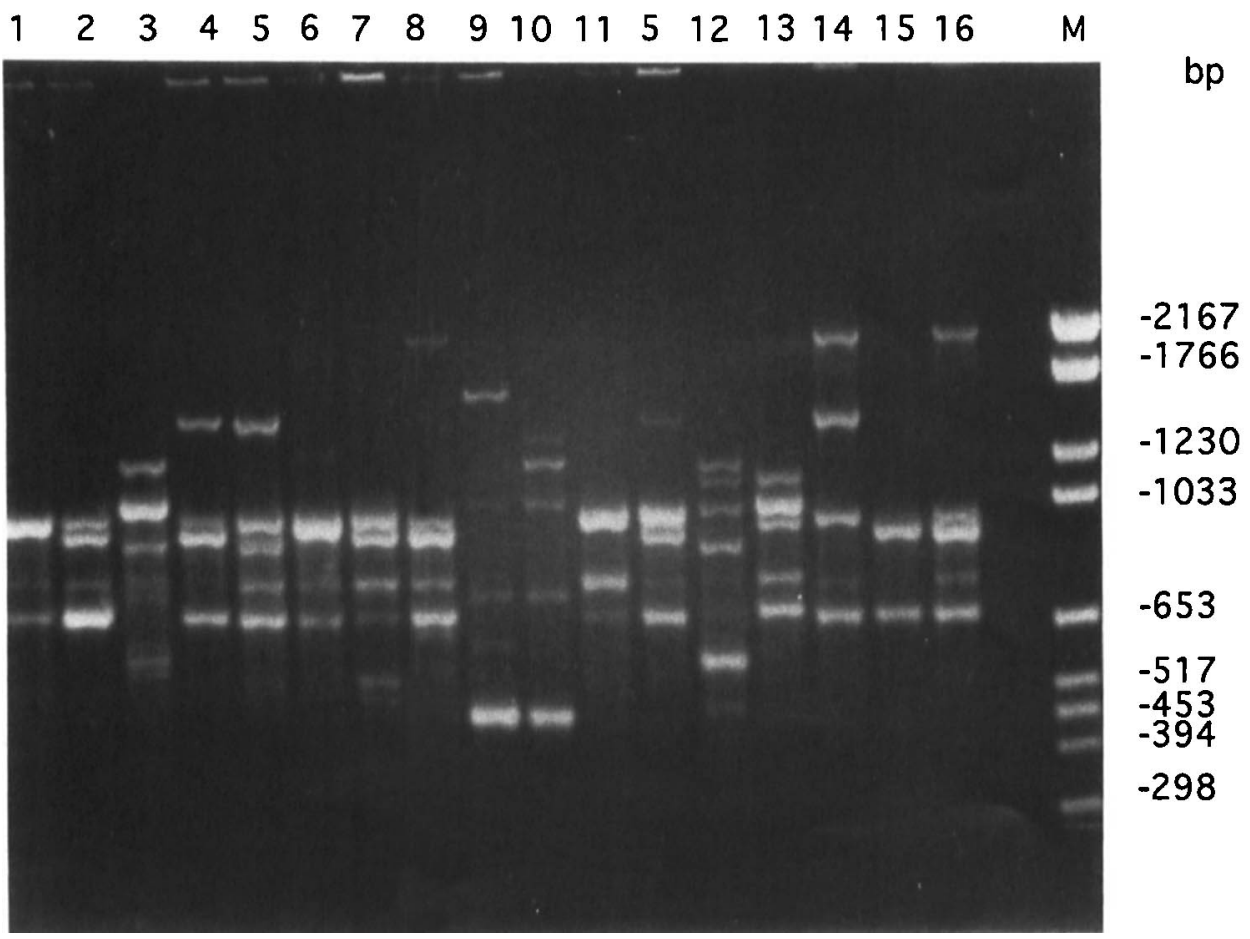

Fig. 4. Patterns obtained by PCR with the M13 core sequence primer (primer concentration $0 \cdot 25 \mu \mathrm{M}$ ). Lane M, DNA mol. wt marker VI (pBR328 DNA-BgII + pBR328 DNA-HinfI). Lane 1, strain 72;2, strains 724,77, 78, 81 and $91 ; 3$, strain 60;4, strain 61; 5, strains 74 and 198 ; 6, strain $58 ; 7$, strains $41,661,88,93,67$ and $70 ; 8$, strains $83,65,31$ and $175 ; 9$, strain $37 ; 10$, strain $167 ; 11$, strains 188 and $182 ; 12$, strain $68 ; 13$, strain $92 ; 14$, strain $36 ; 15$, strain $86 ; 16$, strain 183 . 


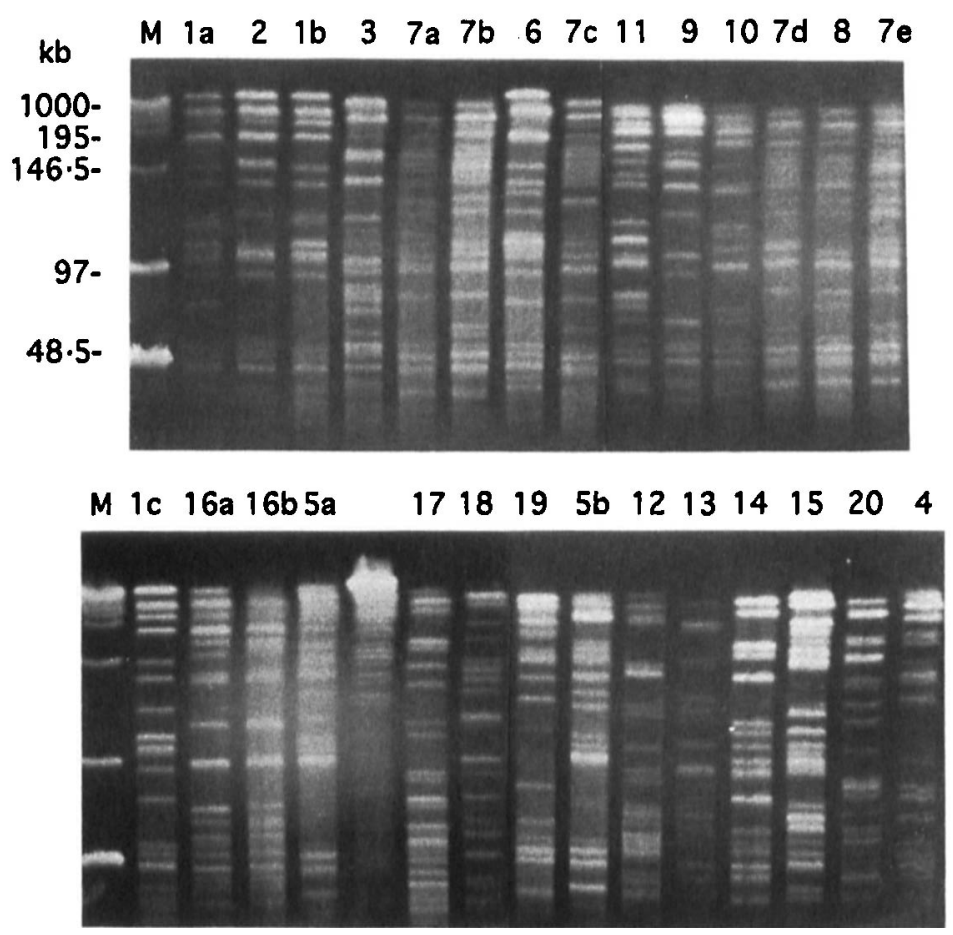

Fig. 5. Chromosomal analysis by PFGE. Digestion of DNA from A. baumannii with ApaI. Lane M, $\lambda$ ladder DNA. Each lane shows the result for a different pattern. Lane 1a, strain 77; 2 , strain $78 ; 1 \mathbf{b}$, strain $81 ; 3$, strain $36 ; 7 \mathbf{a}$, strain $70 ; 7 \mathbf{b}$, strain $661 ; 6$, strain $724 ; 7 \mathbf{c}$, strains 41 and $93 ; 11$, strain $72 ; 9$, strain $86 ; 10$, strain $65 ; 7 \mathrm{~d}$, strain $88 ; 8$, strain $58 ; 7 \mathrm{e}$, strain $67 ; 1 \mathrm{c}$, strain $91 ; 16 \mathrm{a}$, strain $31 ; 16 \mathrm{~b}$, strain $175 ; 5 \mathrm{a}$, strain $188 ; 17$, strain $167 ; 18$, strain $37 ; 19$, strain $183 ; 5 b$, strain $182 ; 12$, strain $60 ; 13$, strain $68 ; 14$, strain $74 ; 15$, strain $83 ; 20$, strain $92 ; 4$, strain 61.

Table III. Reproducibility and discriminatory index of six methods used to type 92 isolates of $A$. baumannii.

\begin{tabular}{lccc}
\hline Typing system & Number of types & Discrimination index & Reproducibility \\
\hline Biotyping (API-20NE) & 3 & 0.659 & + \\
Biotyping (carbon source & 7 & 0.736 & + \\
system) & & & + \\
Antimicrobial susceptibility (AS) & 8 & 0.844 & + \\
Plasmid profile analysis (PPA) & 8 & 0.709 & ++ \\
Whole-cell protein analysis & 8 & 0.727 & + \\
Pulsed-field gel electrophoresis & 29 & 0.962 & + \\
(PFGE) & & & \\
Arbitrary primed polymerase & 16 & 0.872 & \\
chain reaction (AP-PCR) & & & \\
AS and PPA & 9 & 0.854 & \\
AS and PFGE & 29 & 0.962 & \\
AS and AP-PCR & 18 & 0.927 & \\
PFGE and PPA & 29 & 0.962 & \\
PFGE and AP-PCR & 29 & 0.962 & \\
AP-PCR and PPA & 18 & & \\
& & & \\
\hline
\end{tabular}

+ , moderate; ++ , good; +++ , excellent.

patterns were observed when the DNA was digested with ApaI (table I); each one was designated with an ordinal number. Isolates with similar but not identical patterns, differing in three or fewer restriction fragments, were classified as subtypes of the same strain (e.g. la, b, c), while organisms differing by more than three restriction fragments were considered sufficiently divergent to warrant a separate strain designation (fig. 5). The genomic DNA of the strains was also cut by $S m a I$, but the resulting groups were not different from those obtained with ApaI. However, the analysis of genomic DNA of strain no. 198, which was not cut by $A p a \mathrm{I}$, generated a pattern different from that of the other isolates when it was cut with SmaI (data not shown); therefore, 21 patterns were exhibited.

\section{Discriminatory power and reproducibility}

The discriminatory power and the reproducibility of each typing methods are shown in table III. Biotyping, 
whole-cell protein and plasmid analysis were the least discriminatory methods $(0.659 / 0.736,0.727$ and 0.709 , respectively). Antimicrobial susceptibility and APPCR showed moderate discriminatory power $(0.844$ and 0.872 , respectively). Typing based on PFGE of chromosomal DNA appeared to be the most discriminatory method (discrimination index of 0.962).

\section{Discussion}

A significant increase in the isolation of $A$. baumannii has been noted in Spanish hospitals during the last few years, particularly in intensive care units and among immunocompromised patients. The absence of a gold standard typing system for $A$. baumannii is a major problem in epidemiological studies of this organism. Six different typing methods were used to study 92 isolates of $A$. baumannii. Of these, 38 were clinical isolates from a previously defined outbreak ${ }^{3}$ in which two different strains (strain type nos. 41 and 36) were involved, and 54 were randomly selected clinical isolates of $A$. baumannii from three hospitals, presumably derived from sporadic cases of infection. The primary epidemiological marker is the accurate identification of a bacterial isolate at the species level. Early attempts in biotyping Acinetobacter strains relied on gelatinase production, haemolysis, and acid production from glucose. ${ }^{28}$ Further attempts at biotyping were published by Towner and Chopade ${ }^{29}$ who used a commercially available 20 -test identification system, which allowed the differentiation of seven biotypes of $A$. calcoaceticus var. anitratus, with the predominance of biotype 4041473. In the present study, the API-20NE test system made it possible to differentiate only three possible biotypes $(0041073,0041051,0041473)$. More recently, a biotyping system based on the utilisation of six carbon sources allowed Bouvet and Grimont ${ }^{6}$ to identify 19 biotypes of $A$. baumannii, with biotypes 1 , 2, 6 and 9 being found most frequently. Biotypes 2,9 and 12 were the most frequent in our study. The correlation between the API-20NE system and the carbon source utilisation tests was $87 \%$, and both methods had a low discriminatory power -0.659 and 0.736 respectively.

Antibiotic resistance patterns have been used to differentiate strains involved in outbreaks. ${ }^{5,11,30,31}$ Although antimicrobial susceptibility testing is important in detecting new resistant phenotypes, the main limitation of this method as an epidemiological tool is its lack of specificity, as strains with identical antibiograms proved to be quite different by other methods (e.g., strain nos. 74 and 83), and the converse is also true (e.g., strain nos. 41 and 661). Antibiograms may be considered in initial screening to determine strain relatedness, but other epidemiological markers should be used.

Plasmid profiling has been shown to be a valuable epidemiological tool for typing $A$. baumannii. ${ }^{32-33}$ However, it is well known that nosocomial microorganisms may gain or lose plasmids and that repeated sub-culturing and storing may also result in loss of plasmids. In this study, $30.4 \%$ of strains did not contain detectable plasmid DNA, a percentage higher than that reported by Gerner-Schmidt, ${ }^{17}$ making it necessary to use this typing method in conjunction with other ones.

One-dimensional SDS-PAGE has been described previously as a useful tool for typing Acinetobacter spp. ${ }^{14,15}$ However, we found that the two strains responsible for the outbreak had the same protein pattern, but they were clearly differentiated by other epidemiological markers. Nevertheless, protein patterns were useful for differentiating strains with identical antibiogram pattern and without plasmids.

Graser $e t a .^{21}$ amplified DNA of $A$. baumannii with the core sequence of the M13 phage as a single primer and found a discrimination power similar to that of PFGE. Their results contrast with ours, because we found PFGE to have a higher discriminatory power $(0.962)$ than AP-PCR (0.872). Results of PFGE and AP-PCR suggested that one of the strains of the outbreak (strain no. 41) had become an endemic strain in the same hospital and had developed resistance to ciprofloxacin. It also appears that strain no. 41 and several strains from hospital Valle de Hebrón (strain nos $93,67,70$ and 88) were similar, suggesting interhospital transmission.

PFGE of chromosomal DNA enables optimal discrimination of isolates with a single test. The use of other typing methods such as PCR or antibiogram together with PFGE did not increase the discrimination index further (table III). However, PFGE has two disadvantages: first, the prolonged time needed to perform the technique and second, it is necessary to make computerised comparisons of patterns when studying large number of strains. Thus, from our experience, it seems that a combination of an easy and rapid technique such as AP-PCR and a more discriminative but more complex technique such as PFGE may be optimal for epidemiological purposes.

This work was supported in parts by grants from Hospital Clínico y Provincial, Barcelona, Spain, and from DGICYT-Spain (PB88/0206). We thank Dr C. Fernandez (Hospital Valle de Hebrón) and Dr G. Prats (Hospital San Pablo) for providing strains of Acinetobacter.

\section{References}

1. Hartstein AI, Morthland VH, Rourke JW et al. Plasmid DNA fingerprinting of Acinetobacter calcoaceticus subspecies anitratus from intubated and mechanically ventilated paints. Infect Control Hosp Epidemiol 1990; 11: 531-537.

2. Castle M, Tenney JH, Weinstein MP, Eickhoff TC. Outbreak of a multiply resistant Acinetobacter in a surgical intensive care unit: epidemiology and control. Heart Lung 1978; 7 : 641-644.

3. Vila J, Almela M, Jimenez de Anta MT. Laboratory investigation of a hospital outbreak caused by two different 
multiresistant Acinetobacter calcoaceticus subsp. anitratus strains. J Clin Microbiol 1989; 27: 1086-1089.

4. Bergogne-Bérézin E, Joly-Guillou ML, Vieu JF. Epidemiology of nosocomial infections due to Acinetobacter calco aceticus. J Hosp Infect 1987; 10: 105-113.

5. French GL, Casewell MW, Roncoroni AJ, Knight S, Phillips I. A hospital outbreak of antibiotic-resistant Acinetobacter anitratus: epidemiology and control. J Hosp Infect 1980; 1 125-131.

6. Bouvet PJM, Grimont PAD. Identification and biotyping of clinical isolates of Acinetobacter. Ann Inst Pasteur/ Microbiol 1987; 138: 569-578.

7. Berk SL, McCabe WR. Meningitis caused by Acinetobacter calcoaceticus var anitratus. Arch Neurol 1981; 38 : 95-98.

8. Buxton AE, Anderson RL, Werdegar D, Atlas E. Nosocomial respiratory tract infection and colonization with Acinetobacter calcoaceticus. Epidemiologic characteristics. Am J Med 1978; 65: 507-513.

9. Raz R, Alroy G, Sobel JD. Nosocomial bacteremia due to Acinetobacter calcoaceticus. Infection 1982; 10: 168-171.

10. Joly-Guillou ML, Bergogne-Berezin E, Vieu JF. Épidémiologie et résistance aux antibiotiques des Acinetobacter en milieu hospitalier: Bilan de 5 années. Presse Méd 1990; 19 357-361.

11. Vila J, Marcos MA, Marco F et al. In vitro antimicrobial production of $\beta$-lactamases, aminoglycoside-modifying enzymes, and chloramphenicol acetyltransferase by and susceptibility of clinical isolates of Acinetobacter baumannii. Antimicrob Agents Chemother 1993; 37: $138-141$.

12. Bouvet PJM, Jeanjean S, Vieu J-F, Dijkshoorn L. Species, biotype, and bacteriophage type determinations compared with cell envelope protein profiles for typing Acinetobacter strains. J Clin Microbiol 1990; 28: 170-176.

13. Allen KD, Green HT. Hospital outbreak of multi-resistant Acinetobacter anitratus: an airborne mode of spread? Hosp Infect 1987; 9: 110-119.

14. Alexander M, Ismail F, Jackman PJH, Noble WC. Fingerprinting Acinetobacter strains from clinical sources by numerical analysis of electrophoretic protein patterns. $J$ Med Microbiol 1984; 18: 55-64.

15. Vila J, Canales MA, Marcos MA, Gomez-Lus R, Jimenez de Anta MT. Molecular epidemiological analysis of nosocomial Acinetobacter baumannii isolates. In: Towner $\mathrm{KJ}$, Bergogne-Bérézin E, Fewson CA (eds) The biology of Acinetobacter. Taxonomy, clinical importance, molecular biology, physiology, industrial relevance. New York, Plenum Press. 1991: 69-76.

16. Dijkshoorn L, van Viaven W, Degener JE, Michel MF. Typing of Acinetobacter calcoaceticus strains isolated from hospital patients by cell envelope protein profiles. Epidemiol Infect 1987; 99: 659-667.

17. Gerner-Smidt P. Frequency of plasmids in strains of Acinetobacter calcoaceticus. J Hosp Infect 1989; 14: 23-28.

18. Joly-Guillou ML, Bergogne-Bérézin E, Vieu JF. Study of the relationships between antibiotic resistance phenotypes, phage-typing and biotyping of 117 clinical isolates of Acinetobacter spp. J Hosp Infect 1990; 16: 49-58.

19. Gerner-Smidt P. Ribotyping of Acinetobacter calcoaceticusAcinetobacter baumannii complex. J Clin Microbiol 1992; 30: $2680-2685$.

20. Dijkshoorn L, Aucken HM, Gerner-Smidt P, Kaufmann ME, Ursing J, Pitt TL. Correlation of typing methods for Acinetobacter isolates from hospital outbreaks. $J$ Clin Microbiol 1993; 31: 702-705.

21. Graser Y, Klare I, Halle E et al. Epidemiological study of an Acinetobacter baumannii outbreak by using polymerase chain reaction fingerprinting. J Clin Microbiol 1993; 31: 2417-2420.

22. Allardet-Servent A, Bouziges N, Carles-Nurit M-J, Bourg G, Gouby A, Ramuz M. Use of low-frequency-cleavage restriction endonucleases for DNA analysis in epidemiological investigations of nosocomial bacterial infections. $J$ Clin Microbiol 1989; 27: 2057-2061.

23. Gouby A, Carles-Nurit M-J, Bouziges N, Bourg G, Mesnard R, Bouvet PJM. Use of pulsed-field gel electrophoresis for investigation of hospital outbreaks of Acinetobacter baumannii. J Clin Microbiol 1992; 30: 1588-1591.

24. Bauer AW, Kirby WM, Sherris JC et al. Antibiotic susceptibility testing by a standardized single disk method. Am J Clin Pathol 1966; 45: 493-496.

25. Laemmli UK. Cleavage of structural proteins during the assembly of the head of bacteriophage T4. Nature 1970; 227: 680-685.

26. Birnboim HC, Doly J. A rapid alkaline extraction procedure for screening recombinant plasmid DNA. Nucleic Acids Res 1979; 7: 1513-1517.

27. Hunter PR, Gaston MA. Numerical index of the discriminatory ability of typing systems: an application of Simpson's index of diversity. $J$ Clin Microbiol 1988; 26: 2465-2466.

28. Gilardi GL. Identification of miscellaneous glucose non-fermenting Gram-negative bacteria. In: Gilardi GL (ed) glucose non-fermenting Gram-negative bacteria in clinical microbiology. West Palm Beach, CRC Press. 1978: 45-69.

29. Towner KJ, Chopade BA. Biotyping of Acinetobacter calcoaceticus using the API 20NE system. J Hosp Infect 1987; 10: $145-151$.

30. Holton J. A report of a further hospital outbreak caused by a multi-resistant Acinetobacter anitratus. J Hosp Infect 1982; 3: 305-309.

31. Crombach WHJ, Dijkshoorn $\mathbf{L}$, van Noort-Klaassen $\mathbf{M}$, Niessen J, van Knippenberg-Gordebeke G. Control of an epidemic spread of a multi-resistant $K$ strain of Acinetobacter calcoaceticus in a hospital. Intens Care Med 1989; 15: 166-170.

32. Beck-Sagué CM, Jaarvis WR, Brook JH et al. Epidemic bacteremia due to Acinetobacter baumannii in five intensive care units. Am J Epidemiol 1990; 132: 723-733.

33. Patterson JE, Vecchio J, Pantelick EL et al. Association of contaminated gloves with transmission of Acinetobacter calcoaceticus var, anitratus in an intensive care unit. $A m J$ Med 1991; 91 : 479-483. 